\title{
BALINISASI MASAKAN VEGETARIAN
}

\author{
oleh, \\ I Wayan Suja dan Nyoman Retug \\ Jurusan Pendidikan Kimia \\ Fakultas Matematika dan Ilmu Pengetahuan Alam \\ Universitas Pendidikan Ganesha
}

\begin{abstract}
ABSTRAK
Kesadaran masyarakat untuk beralih kepada makanan alami, termasuk makanan vegetarian, sesungguhnya memberikan peluang bisnis bagi mereka yang bergerak dalam bidang usaha kuliner. Peluang tersebut semula hanya dimanfaatkan oleh warga keturunan dengan menyediakan masakan Cina, yang selain terasa aneh di lidah, juga tergolong mahal. Untuk itu, dipandang perlu untuk membalinisasi masakan vegetarian bekerja sama dengan mitra lokal yang bergerak dalam bidang usaha kuliner vegetarian. Dua mitra telah dilibatkan, yaitu Depot Vegetarian Bhoga Laksmi dan Depot Vegetarian $\mathrm{Bu}$ Krisna, yang masing-masing berlokasi di sebelah Timur dan Barat kota Singaraja, Bali. Dari wawancara dan observasi awal ditemukan bahwa kedua mitra masih perlu diberikan pemahaman berkaitan dengan seluk-beluk vegetarian dan dilatih membuat masakan vegetarian khas Bali, termasuk penggunaan bumbu-bumbu Bali (basa genep). Kegiatan IbM ini dilaksanakan untuk meningkatkan pemahaman dan keterampilan mitra dalam membuat masakan vegetarian dengan nuansa Bali menggunakan bahan-bahan dan bumbu lokal dan alami. Kegiatan dilakukan dengan metode pelatihan, yang meliputi diskusi dan praktek. Hasil kegiatan berupa pemahaman dan kemampuan mitra untuk mengkomunikasikan makanan vegetarian semakin mantap, serta terampil membalinisasi masakan vegetarian. Masakan vegetarian yang dihasilkan dalam kegiatan IbM ini memiliki karakteristik sebagai berikut. Pertama, jenis masakannya mengikuti makanan tradisional Bali atau sudah diadaptasi dalam khasanah budaya kuliner Bali. Jenis-jenis masakan tersebut, meliputi lawar, tum, sate, urutan, be siap sitsit, be kuah, rawon, ati, syobak, plecing, dan lain-lainnya. Kedua, menurut konsumen tekstur masakan vegetarian yang dibuat sudah sangat mirip dengan masakan produk daging hewani. Ketiga, bumbu yang digunakan merupakan produk sendiri menggunakan bahan-bahan alami lokal. Penggunaan bumbu lokal tersebut (terutama basa gede/basa genep) menyebabkan masakan vegetarian yang dihasilkan memiliki aroma dan rasa sesuai dengan selera masyarakat Bali. Ketiga spesifikasi tersebut merupakan keunggulan masakan vegetarian khas Bali yang dihasilkan, sebagai produk usaha kreatif untuk membalinisasi masakan vegetarian. Inovasi produk dan peningkatan pelayanan kepada pelanggan telah berdampak positif terhadap penghasilan harian mereka. Semula penghasilan per hari kedua mitra masing-masing berkisar antara Rp.150 - 200 ribu, setelah pelatihan mencapai Rp. 275 - 400 ribu rupiah.
\end{abstract}

Kata-kata kunci : vegetarian khas Bali, basa genep. 


\section{Pendahuluan}

Dalam satu dasa warsa terakhir di Bali muncul trend masyarakat menjalani hidup vegetarian. Ada tiga alasan seseorang memutuskan diri untuk menjalani hidup vegetarian atau setidaknya mengurangi mengkonsumsi daging, yaitu kesadaran akan pentingnya hidup sehat secara jasmani dan rohani, pembiasaan menyayangi kehidupan (termasuk binatang), dan penanggulangan pemanasan global (global warming). Gerakan masyarakat tersebut mendapat sambutan positif dari Gubernur Bali, Made Mangku Pastika, yang mendeklarasikan kepada masyarakat dunia, bahwa tanggal 27 Maret sebagai hari Vegan Organik Dunia (World Vegan Organic Day) dan hari Jumat sebagai hari tanpa produk hewani (Friday-free animal product day).

Dukungan Gubernur Bali terhadap upaya penanggulangan pemanasan global memunculkan berbagai gerakan "be vegan, go green to save the planet." Gerakan tersebut dimotori oleh Bali Green Community yang keanggotaannya bersifat lintas agama/keyakinan, lintas budaya, lintas paham politik, dan lintas etnis. Di Singaraja gerakan tersebut didukung oleh berbagai organisasi sosial-spiritual yang telah ada sebelumnya, seperti Ananda Marga, Kesadaran Krishna, Japa Yoga, Reyki, Rada Swami, Tao, Loving Hurt, Asosiasi Supreme Master Ching Hai, dan Sai Study Group.

Gerakan be vegan membuka peluang munculnya banyak café vegetarian. Sekarang ini di kota Singaraja telah ada 11 café dan warung vegetarian, yang sebagian besar dikelola oleh warga keturunan dengan masakan Cinanya (Chinese food). Dari wawancara dengan pengelola warung-warung vegetarian tersebut diketahui rata-rata pengunjung setiap harinya sekitar 40 orang. Jika rata-rata setiap pengunjung memiliki 4 orang keluarga vegetarian, maka perhitungan kasar jumlah orang vegetarian di kota Singaraja adalah sebanyak 1.700 orang dan cenderung meningkat setiap tahunnya. Kecenderungan tersebut disambut oleh para "wirausahawan" dengan membuka warungwarung makan vegetarian.

Masakan "daging" nabati yang disediakan di warung-warung tersebut tidak jarang asing bagi lidah orang Bali, di samping harganya relatif mahal. Dari sekian banyak café dan warung vegetarian yang ada di kota Singaraja, dua di antaranya dikelola oleh penduduk lokal (asli Bali), yaitu "Depot Vegetarian Bhoga Laksmi” yang dikelola oleh Ibu Ni Nengah Supeni dan "Depot Vegetarian Bu Krisna" dikelola oleh Ibu Luh 
Sudimpen, S.H. Kedua depot vegetarian yang dikelola oleh masyarakat asli Bali tersebut perlu mendapatkan pembinaan dengan tujuan sebagai berikut. Pertama, pemberdayaan dan pemertahanan masyarakat Bali yang berusaha dalam bidang ekonomi kerakyatan agar mampu bersaing dengan para pendatang. Kedua, pemertahanan seni kuliner Bali terhadap gempuran kuliner global, termasuk masakan vegetarian. Ketiga, mengakrabkan lidah masyarakat Bali dengan berbagai produk masakan vegetarian melalui proses globalinisasi kuliner, baik bahan, jenis, bentuk, maupun bumbunya, sehingga sesuai dengan selera masyarakat Bali. Keempat, untuk menekan harga masakan vegetarian, sehingga terjangkau oleh masyarakat menengah ke bawah yang memiliki kesadaran untuk menjadi seorang vegetarian atau mengurangi mengkonsumsi produk daging.

Peluang bisnis masakan vegetarian khas Bali tergolong sangat terbuka dan strategis. Para pelanggannya berasal dari berbagai komunitas dan profesi, seperti anggota-anggota kelompok spiritual (termasuk mereka yang pantang makan bawang merah, bawang putih, dan bahan tambahan makanan non organik), praktisi kesehatan (tenaga medis), para manula, penderita penyakit tertentu, pencinta lingkungan, dan masyarakat awam yang belajar mengurangi ketergantungan makan produk daging hewani. Peluang tersebut bisa diraih jika mitra memahami keinginan pelanggan dan mampu memberikan informasi berkaitan dengan permasalahan yang mereka hadapi berkaitan dengan pola hidup vegetarian.

Melalui observasi pendahuluan dan wawancara mendalam dengan pemilik dua warung vegetarian yang akan dijadikan mitra kegiatan $\mathrm{I}_{\mathrm{b}} \mathrm{M}$ ini, didapatkan kondisi umum ke dua warung tersebut seperti terlihat pada Tabel 1.

\begin{tabular}{|c|l|l|l|}
\hline No & \multicolumn{1}{|c|}{ Uraian } & \multicolumn{1}{|c|}{$\begin{array}{c}\text { Depot Vegetarian } \\
\text { "Bhoga Laksmi” }\end{array}$} & \multicolumn{1}{|c|}{$\begin{array}{c}\text { Depot Vegetarian } \\
\text { "Bu Krisna" }\end{array}$} \\
\hline 1 & Pemilik & Ni Nengah Supeni & Luh Sudimpen, SH. \\
\hline 2 & Tempat & Jl. Gempol 40 Banyuning & $\begin{array}{l}\text { Jl. Laksamana 104A } \\
\text { Baktisraga }\end{array}$ \\
\hline 3 & Mulai usaha & September 2011 & Juli 2010 \\
\hline 4 & $\begin{array}{l}\text { Modal awal, termasuk sewa } \\
\text { tempat }\end{array}$ & Rp. 12.000.000,00 & Rp. 17.000.000,00 \\
\hline 5 & Modal harian & Rp. 200.000,00 & Rp. 200.000,00 \\
\hline 6 & Penghasilan bersih harian & Rp. 200.000,00 & Rp. 150.000,00 \\
\hline
\end{tabular}


\begin{tabular}{l|l|l|l}
7 & $\begin{array}{l}\text { Jumlah pengunjung } \\
\text { (makan/beli lauk) }\end{array}$ & \pm 35 orang & \pm 30 orang \\
\hline
\end{tabular}

Melalui wawancara dan observasi lapangan juga berhasil diungkap permasalahan yang dihadapi oleh ke dua depot vegetarian tersebut tidak jauh berbeda, baik dari aspek produksi maupun manajemen usahanya. Permasalahan yang dihadapi berkaitan dengan aspek produksi adalah sebagai berikut. 1) Bahan masakan yang disediakan di kedua depot vegetarian tersebut adalah gluten dan proteina. Gluten berupa bahan yang bersifat kenyal dan kaya akan protein, berasal dari sisa remasan tepung terigu, yang tidak larut dalam air. Ke dua bahan tersebut merupakan produk olahan pabrik, sehingga tidak segar dan kemungkinan tidak bebas bahan-bahan aditif makanan yang secara akumulatif bisa berbahaya bagi kesehatan konsumen. 2) Variasi jenis masakan vegetarian yang disediakan sebagian masih meniru masakan luar, seperti siobak dan kare yang merupakan jenis masakan Cina. Kondisi itu menyebabkan masakan vegetarian relatif asing bagi masyarakat Bali. 3) Pengolahan tepung menjadi gluten yang dilakukan oleh pemilik kedua depot vegetarian tersebut tampaknya belum sempurna, sehingga produk olahan makanan yang dihasilkannya masih terasa tepung dan tidak tahan lama. 4) Bumbu masakan yang dipakai sebagian menggunakan produk jadi yang telah disediakan oleh pabrik. Akibatnya, rasa masakan vegetarian tersebut banyak tidak sesuai dengan selera lidah masyarakat Bali, yang umumnya menyenangi rasa agak pedas, dan relatif banyak bumbu. Selain mengalami kelemahan dari aspek produksi, kedua depot vegetarian tersebut belum mampu menyediakan berbagai informasi yang diperlukan oleh konsumen berkaitan dengan masakan vegetarian, terutama dampaknya terhadap kesehatan fisik, psikis, dan spiritual. Informasi tersebut sangat diperlukan, mengingat sampai sekarang masih ada pandangan keliru berkaitan dengan vegetarian.

Sumber inspirasi dalam kegiatan $\mathrm{I}_{b} \mathrm{M}$ ini adalah adanya peluang besar dalam usaha kuliner vegetarian, khususnya yang mampu menyediakan masakan sesuai dengan selera lidah masyarakat Bali. Masyarakat sudah mulai menyadari, bahwa mengkonsumsi masakan enak dan lezat dari bahan daging, telah banyak menimbulkan berbagai penyakit dan secara tidak langsung juga berkontribusi terhadap terjadinya pemanasan global. Pandangan tersebut menyebabkan banyak masyarakat berusaha mengurangi makan daging dan berpaling kepada masakan vegetarian, namun perubahan tersebut 
masih susah dilakukan karena daging nabati relatif tidak enak dan mahal. Selain itu, menu yang disediakan oleh warung-warung vegetarian dalam bentuk masakan Cina juga masih asing bagi sebagian besar lidah masyarakat Bali. Kondisi itu memberikan peluang untuk melakukan pembinaan kepada warung-warung masakan vegetarian pribumi yang memiliki keinginan untuk mengembangkan masakan vegetarian khas Bali, dengan menggunakan bahan-bahan alami produk lokal, memproduksi masakan khas Bali, serta memiliki cita rasa sesuai dengan selera lidah orang Bali yang didukung dengan bumbu-bumbu lokal.

\section{Metode Pelaksanaan Pengabdian}

Masalah pokok dalam kegiatan IbM ini berkaitan dengan ketidakmampuan mitra untuk menyediakan masakan vegetarian sesuai dengan selera lidah masyarakat Bali dan memberikan informasi yang diperlukan oleh konsumen berkaitan dengan vegetarian. Berbagai alternatif untuk memecahkan kedua permasalahan terlihat pada Tabel 1.

Tabel 1. Alternatif Pemecahan Masalah

\begin{tabular}{|c|c|c|c|}
\hline No & Permasalahan & Akar masalah & $\begin{array}{c}\text { Alternatif } \\
\text { Pemecahan Masalah } \\
\end{array}$ \\
\hline 1. & $\begin{array}{l}\text { Tidak adanya informasi } \\
\text { berkaitan } \\
\text { kadungan gizi menu } \\
\text { vegetarian } \\
\text { dampaknya terhadap } \\
\text { kesehatan fisik, psikis, } \\
\text { dan spiritual konsumen. }\end{array}$ & $\begin{array}{l}\text { Belum ada ke-sempatan } \\
\text { dan kemampuan untuk } \\
\text { menyiapkan informasi } \\
\text { tertulis. }\end{array}$ & $\begin{array}{l}\text { Eksplorasi dan diskusi } \\
\text { permasalah-an yang } \\
\text { dihadapi mitra berkaitan } \\
\text { dengan pola makan } \\
\text { vegetarian. } \\
\text { Pembuatan brosur, } \\
\text { booklet, dan poster } \\
\text { tentang vegetarian yang di } \\
\text { dalamnya memuat } \\
\text { keunggulan masakan } \\
\text { vegetarian serta } \\
\text { kontribusi kaum vegan } \\
\text { dalam penanggulangan } \\
\text { masalah sosial dan } \\
\text { lingkungan (pemanasan } \\
\text { global). }\end{array}$ \\
\hline 2. & $\begin{array}{l}\text { Bahan, bumbu, dan } \\
\text { variasi jenis masakan } \\
\text { vegetarian yang disiapkan } \\
\text { masih terbatas, dengan } \\
\text { rasa cukup asing bagi } \\
\text { lidah orang Bali. }\end{array}$ & $\begin{array}{l}\text { Belum banyak ada } \\
\text { upaya } \\
\text { memanfaatkan potensi } \\
\text { lokal dalam pembu-atan } \\
\text { masakan vegetarian. }\end{array}$ & $\begin{array}{l}\text { Pembuatan masakan } \\
\text { vegetarian menggunakan } \\
\text { bahan produk pabrik, } \\
\text { memakai bumbu lokal, } \\
\text { didukung dengan buku } \\
\text { resep masakan vegetarian } \\
\text { khas Bali. } \\
\text { Pembuatan masakan }\end{array}$ \\
\hline
\end{tabular}




\begin{tabular}{|l|l|l|}
\hline & & vegetarian menggunakan \\
& campuran bahan pabrik \\
dan alami, menggunakan \\
bumbu lokal. \\
& $\begin{array}{l}\text { Pengembangan masakan } \\
\text { vegetarian khas Bali: }\end{array}$ \\
& jenis, bahan, dan \\
& bumbunya sesuai potensi \\
& lokal. \\
\hline
\end{tabular}

Berdasarkan rumusan alternatif pemecahan masalah dalam Tabel 1 di atas, solusi yang diambil untuk memecahkan permasalahan tersebut adalah pemberian pelatihan berkaitan dengan masakan vegetarian, yang di dalamnya mencakup kegiatan: 1) diskusi tentang keunggulan dan kelemahan masakan vegetarian dibandingkan dengan non vegetarian, serta 2) pelatihan pembuatan masakan vegetarian dengan sentuhan seni kuliner Bali. Realisasi kegiatan $\mathrm{I}_{b} \mathrm{M}$ ini dimulai dengan sosialisasi kepada mitra untuk mendiskusikan program dan waktu kegiatan secara pasti. Hasil kesepakatan tersebut ditindaklanjuti dengan pelaksanaan kegiatan di tempat mitra secara bergiliran. Secara umum kegiatan $\mathrm{I}_{\mathrm{b}} \mathrm{M}$ berupa diskusi tentang masakan vegetarian dan praktek pembuatan masakan vegetarian khas Bali.

Tabel 2 Kegiatan IbM Depot Vegetarian

\begin{tabular}{|c|c|c|c|c|}
\hline No & Tujuan & Bentuk Kegiatan & Produk & $\begin{array}{l}\text { Nara } \\
\text { sumber }\end{array}$ \\
\hline \multirow[t]{2}{*}{1.} & \multirow{2}{*}{$\begin{array}{l}\text { Untuk meningkatkan } \\
\text { pemahaman dan } \\
\text { kemampuan komunikasi } \\
\text { mitra berkaitan dengan } \\
\text { pola hidup vegetarian } \\
\text { dan kontribusinya dalam } \\
\text { menanggulangi berbagai } \\
\text { masalah sosial dan } \\
\text { lingkungan. }\end{array}$} & $\begin{array}{l}\text { Diskusi kandungan gizi } \\
\text { bahan makanan hewani dan } \\
\text { nabati, bahan tambahan } \\
\text { makanan, serta diit } \\
\text { vegetarian dan non } \\
\text { vegetarian. }\end{array}$ & $\begin{array}{l}\text { Booklet } \\
\text { vegetarian }\end{array}$ & $\begin{array}{l}\text { Drs. I Wayan } \\
\text { Suja, M.Si }\end{array}$ \\
\hline & & $\begin{array}{l}\text { Diskusi kontribusi kelompok } \\
\text { vegetarian terhadap } \\
\text { penanggulangan masalah } \\
\text { sosial dan lingkungan } \\
\text { Diskusi seni kuliner Bali. }\end{array}$ & $\begin{array}{l}\text { Brosur dan } \\
\text { poster } \\
\text { vegetarian } \\
\text { Resep bumbu } \\
\text { Bali }\end{array}$ & $\begin{array}{l}\text { Putu Agus } \\
\text { Mayuni, } \\
\text { S.Pd., M.Si }\end{array}$ \\
\hline 2. & $\begin{array}{l}\text { Untuk melatih mitra agar } \\
\text { mampu membuat } \\
\text { berbagai produk } \\
\text { makanan vegetarian } \\
\text { yang sesuai dengan seni }\end{array}$ & $\begin{array}{l}\text { Praktek pembuatan masakan } \\
\text { vegetarian menggunakan } \\
\text { bahan pabrik, tetapi dengan } \\
\text { jenis dan bumbu lokal. }\end{array}$ & $\begin{array}{l}\text { Buku resep vege } \\
\text { khas Bali. } \\
\text { Produk: sate } \\
\text { laut, sate kam- } \\
\text { bing, urutan, dll. }\end{array}$ & $\begin{array}{l}\text { Drs. Nyoman } \\
\text { Retug, M.Si } \\
\text { Drs. I Wayan } \\
\text { Suja, M.Si }\end{array}$ \\
\hline
\end{tabular}




\begin{tabular}{|l|l|l|l|}
\hline dan selera orang Bali. & Praktek pembuatan masakan & Tum bungkil, \\
& vegetarian menggunakan & kare ayam, tum \\
bahan campuran lokal dan & isi, be guling, be & sisit, syiobak, \\
& pabrik. & dll. \\
& Pengembangan masakan & Lawar kelu- \\
& vegetarian khas Bali, dengan & ngah, lawar \\
& jenis dan bahan seutuhnya & nangka, ares, \\
& lokal & tum nangka, sate & lilit, ati, dll. \\
& & \\
\hline
\end{tabular}

Seluruh program ini melibatkan mitra sebagai pelaku dan sasaran kegiatan. Dengan demikian, partisipasi mereka bersifat total mulai dari perencanaan, penyediaan fasilitas dan sarana, pelaksanaa kegiatan, sampai dengan refleksi dan evaluasi program. Upaya tersebut dilakukan agar mereka mampu mengelola dan mengembangkan usahanya secara mandiri, kreatif, dan produktif. Mereka juga diharapkan secara berkelanjutan dapat mengembangkan masakan vegetarian khas Bali, serta mampu mengkomunikasikan berbagai kajian tentang masakan vegetarian dari aspek ilmiah, sosial, dan spiritualnya. Evaluasi kegiatan ini dilakukan terhadap proses dan produk kegiatan. Evaluasi proses berkaitan dengan kinerja mitra selama pelatihan, sedangkan evaluasi produk berkaitan dengan kualitas masakan vegetarian yang dihasilkan oleh mitra. Evaluasi proses dilakukan oleh Tim Pelaksana IbM, sedangkan evaluasi produk dilakukan oleh konsumen (pembeli) masakan vegetarian tersebut. Kriteria keberhasilan kegiatan IbM ini adalah: 1) kinerja mitra, mencakup kehadiran, semangat mengikuti kegiatan, keterampilan membuat masakan, keingintahuan, dan kerja sama minimal tergolong baik; 2) kualitas masakan vegetarian yang dihasilkan, mencakup tampilan, tekstur, dan rasa; minima juga tergolong baik (disenangi konsumen). Penskoran menggunakan skala Likert, 1 - 5, dengan rerata skor minimal 3,40).

\section{Hasil dan Pembahasan}

Karya utama dalam kegiatan IbM ini adalah masakan vegetarian khas Bali, yang dapat dikelompokkan menjadi tiga, yaitu: 1) masakan vegetarian dengan bahan gluten dan proteina, tetapi mengunakan bumbu lokal; 2) masakan vegetarian dengan bahan campuran produk pabrik dan alam, dengan bumbu lokal; serta 3) masakan vegetarian yang dibuat dari bahan-bahan dan bumbu lokal (bahan-bahan alami). Produk masakan 
vegetarian tersebut sekarang telah menjadi menu masakan di kedua Depot Vegetarian tersebut.

\section{DAFTAR MENU HARIAN DEPOT VEGETARIAN BHOGA LAKSMI DAN BU KRISNA \\ (Bumbu Bali, tanpa bawang merah/putih, MSG, pengrwet, dan pewarna sintetis)}

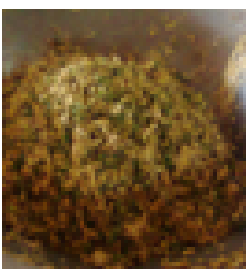

Lawar

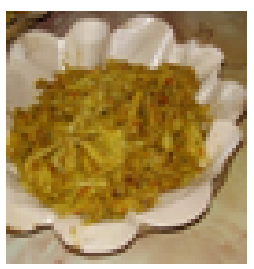

Be Sisit

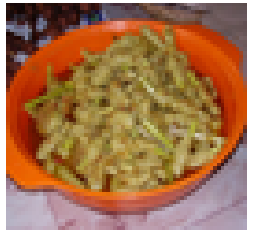

Kare aram

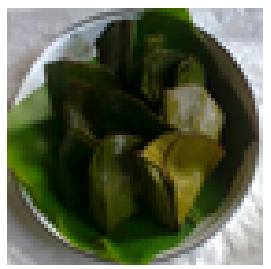

Tum

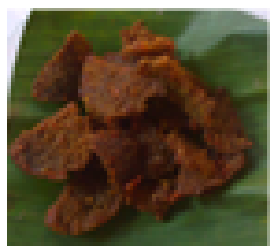

Ati

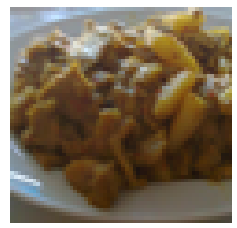

Be Guling

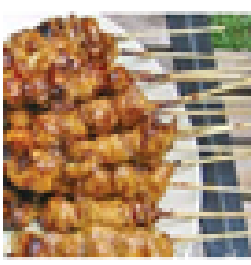

Sote

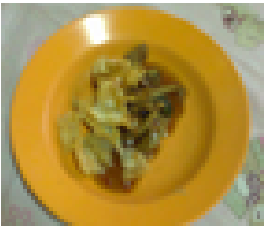

Syobsk

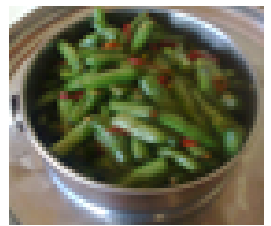

Jukut Buncis

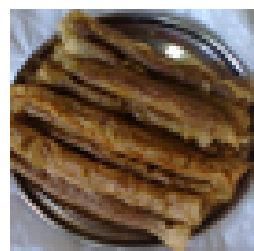

Unutan

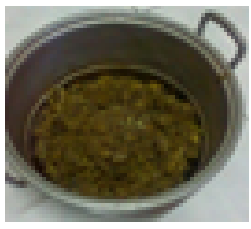

Be Kuwah/Fawon

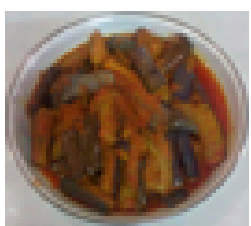

Sambel tuung

Kontak: Bu Raju, B, OB523B3BB74B; (Mitra IbM Depot Vegetarian Undiksha 2012)

Proses pembuatan masakan vegetarian khas Bali tersebut dipaparkan sebagai berikut.

\begin{tabular}{|c|l|}
\hline Sate "kambing" & $\begin{array}{l}\text { Dibuat dari bahan proteina yang sudah tersedia di } \\
\text { toko bahan makanan. Proteina direndam beberapa saat } \\
\text { dalam air panas, dikucek untuk menghilangkan baunya, } \\
\text { ditiris, dipotong-potong untuk mendapatkan ukuran } \\
\text { sesuai keinginan, diolah dengan bumbu Bali. Setelah } \\
\text { ditusuk-tusuk dibakar, kemudian ditambahkan bumbu } \\
\text { plecing }\end{array}$ \\
\hline
\end{tabular}




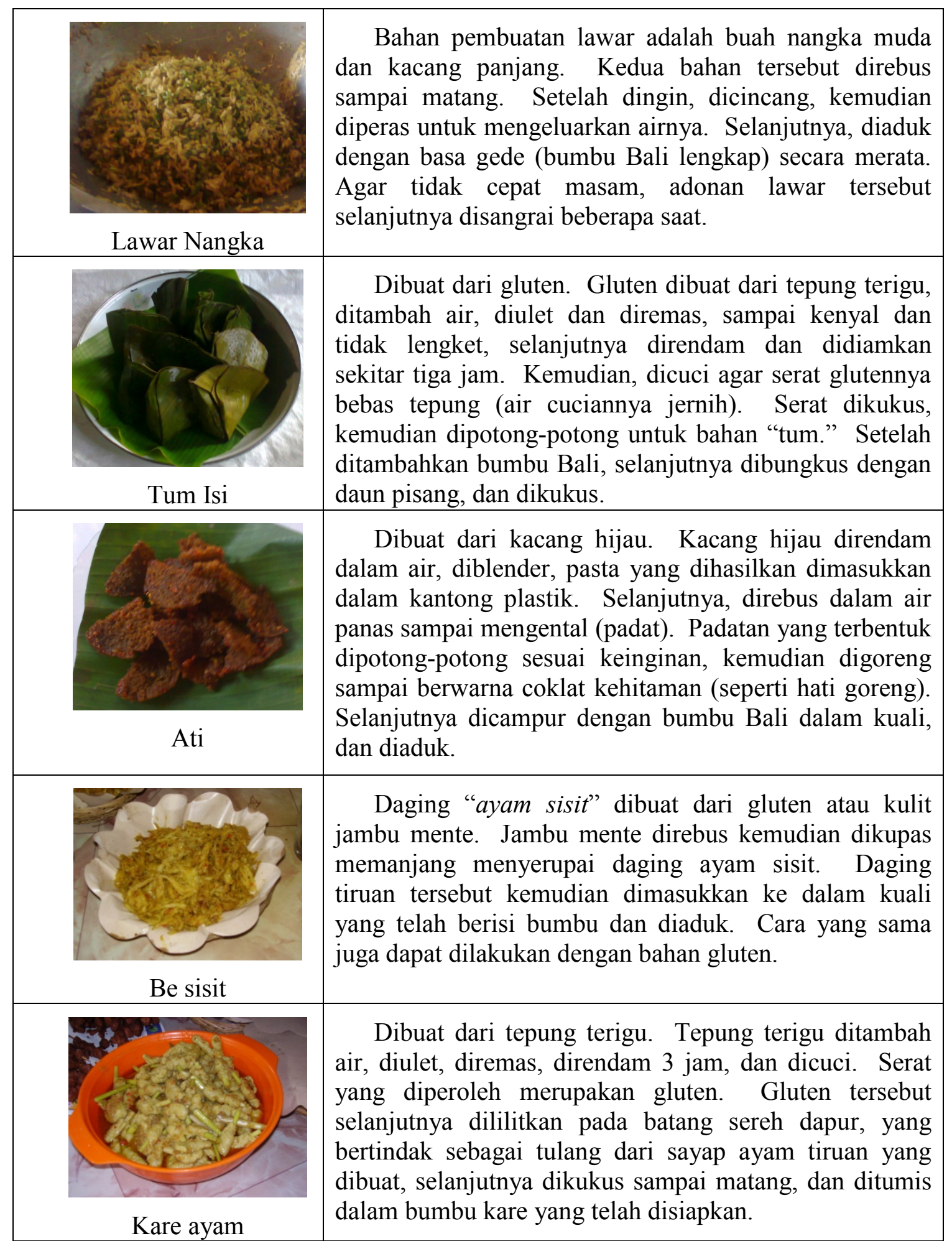




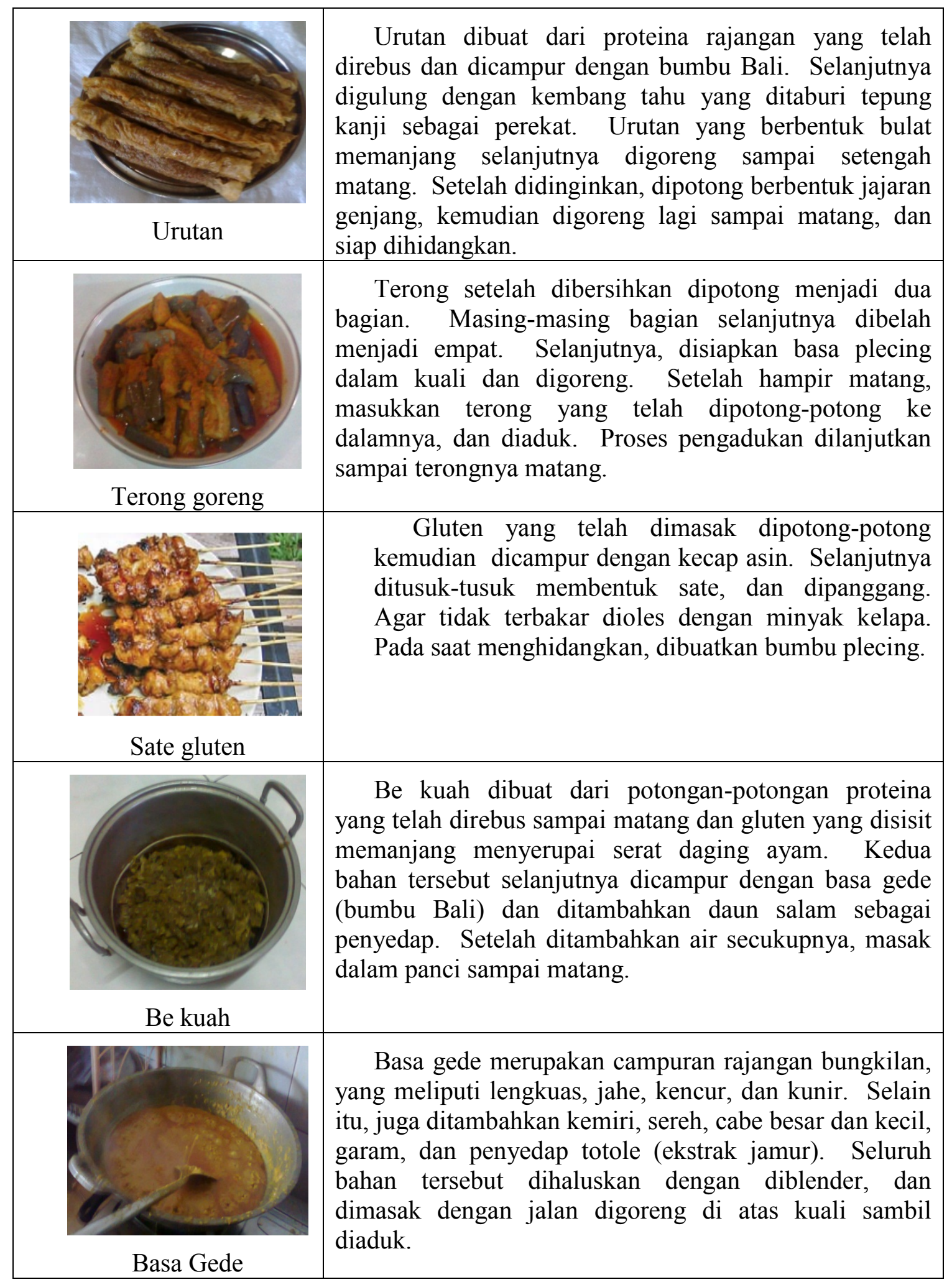




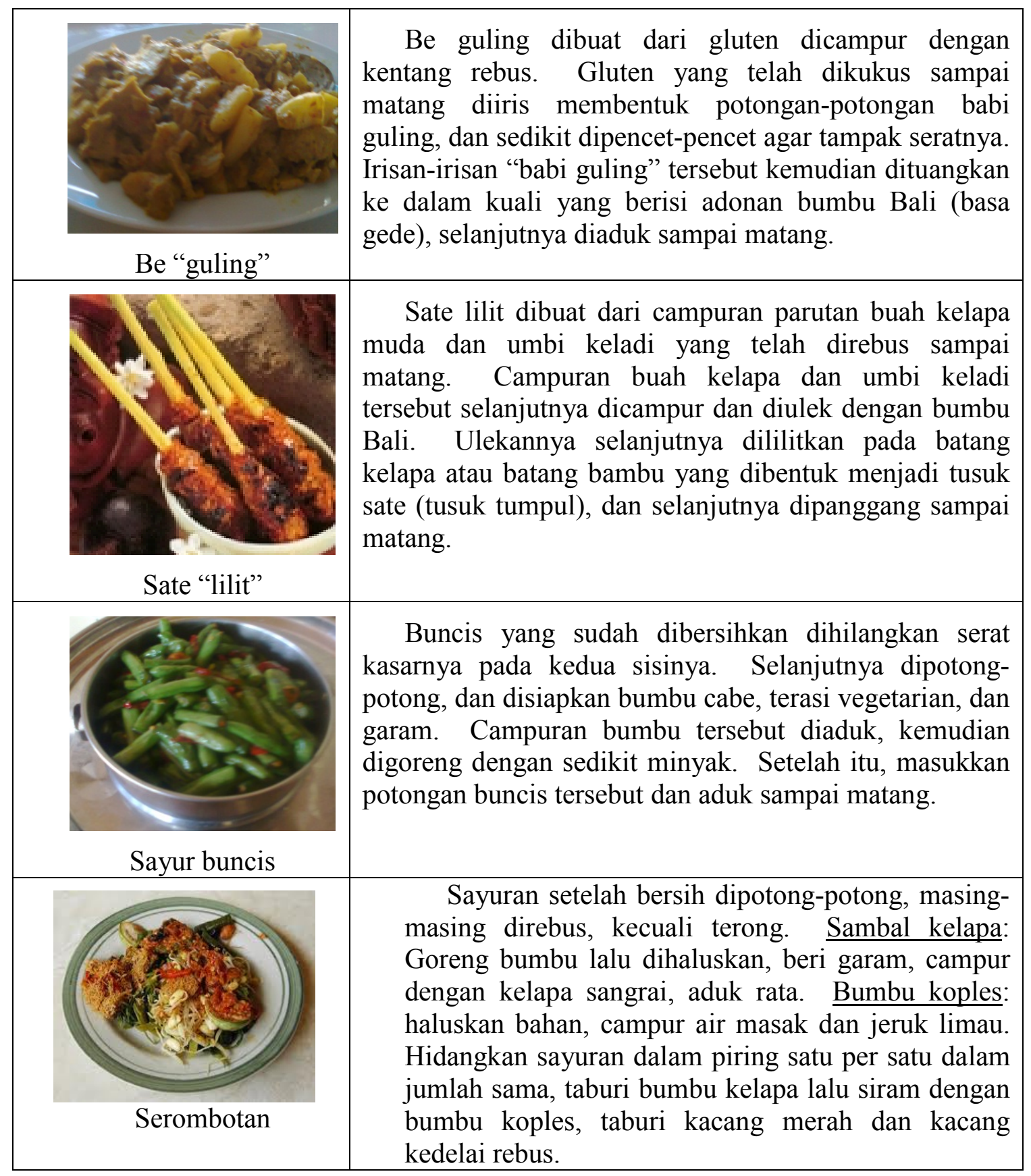

Selama kegiatan berlangsung, dilakukan evaluasi proses oleh tiga orang anggota pelaksana IbM ini. Parameter yang diukur adalah kehadiran mitra, semangat mengikuti kegiatan, keterampilan membuat masakan, keingintahuan, dan kerja sama. Penilaian dilakukan dengan instrumen lembar observasi. Hasil analisis data yang diperoleh menunjukkan bahwa kinerja mitra selama pelatihan tergolong sangat baik (rerata skor 4,93). Untuk mendapatkan data yang paling akurat berkaitan dengan kualitas produk masakan vegetarian yang dihasilkan, telah diambil pendapat para pelanggan terhadap 
masakan vegetarian yang disediakan di kedua mitra setelah mengikuti pelatihan. Dari 27 responden diperoleh data bahwa tingkat kepuasan pelanggan terhadap layanan dan masakan yang disediakan tergolong tinggi (rerata skor 4,49).

Selain terjadi peningkatan kualitas produk masakan vegetarian yang semakin bernuansakan kebaliannya, kedua pemahaman mitra tentang berbagai aspek berkaitan dengan vegetarian juga semakin meningkat. Untuk mendukung kemampuan tersebut, pelaksana IbM juga telah melengkapinya dengan brosur, buku vegetarian, dan resep masakan vegetarian khas Bali. Mereka juga dilatihkan untuk mengedepankan kepuasan psikologis bagi pelanggan, dengan prinsip "Tiga S : senyum, sapa, dan servis."

Masakan vegetarian yang dihasilkan dalam kegiatan IbM ini memiliki karakteristik sebagai berikut. Pertama, jenis masakannya mengikuti makanan tradisional Bali atau sudah diadaptasi dalam khasanah budaya kuliner Bali. Jenis-jenis masakan tersebut, meliputi lawar, tum, sate, urutan, be siap sitsit, be kuah, rawon, ati, syobak, plecing, dan lain-lainnya. Kedua, menurut konsumen tekstur masakan vegetarian yang dibuat sudah sangat mirip dengan masakan produk daging hewani. Ketiga, bumbu yang digunakan merupakan produk sendiri menggunakan bahan-bahan alami lokal. Penggunaan bumbu lokal tersebut (terutama basa gede/basa genep) menyebabkan masakan vegetarian yang dihasilkan memiliki aroma dan rasa sesuai dengan selera masyarakat Bali. Ketiga spesifikasi tersebut merupakan keunggulan masakan vegetarian khas Bali yang dihasilkan, sebagai produk usaha kreatif untuk membalinisasi masakan vegetarian. Inovasi produk dan peningkatan pelayanan kepada pelanggan telah berdampak positif terhadap penghasilan harian mereka. Semula penghasilan per hari kedua mitra masing-masing berkisar antara Rp.150 - 200 ribu, setelah pelatihan mencapai Rp. 275 - 400 ribu rupiah.

\section{Penutup}

Kedua mitra dalam kegiatan IbM ini telah berhasil membalinisasi masakan vegetarian. Mereka telah mampu membuat masakan vegetarian dengan menggunakan bahan-bahan dan bumbu alami yang diproduksinya sendiri. Jenis masakan vegetarian yang dibuat mengikuti masakan tradional Bali, yang tekstur, aroma, dan rasanya tidak jauh berbeda dengan produk aslinya (menggunakan bahan daging). Inovasi produk dan kualitas layanan kepada konsumen telah berdampak positif terhadap penghasilan harian 
kedua mitra Selama melaksanakan kegiatan IbM ini, masih ditemukan kelemahan pada kedua mitra, dimana kontinuitas mitra untuk berjualan sering terganggu oleh kegiatan hari raya, acara ritual keluarga, dan kegiatan sosial lainnya. Karena menutup warung (tidak berjualan), maka bisa menyebabkan pelanggan berpindah kepada pedagang masakan vegetarian lainnya. Untuk itu, ke depan perlu dicarikan solusi dengan pelibatan tenaga kerja yang lebih banyak dan volume usaha yang lebih besar. Untuk itu, perlu diberikan bantuan berkaitan dengan permodalan dan pengembangan usaha mereka. Mereka juga harus tetap kreatif mengembangkan masakan vegetariannya agar tetap dan semakin dicari oleh konsumen.

Kegiatan $\mathrm{I}_{\mathrm{b}} \mathrm{M}$ Depot Vegetarian ini sangat bermanfaat bagi kedua mitra karena mereka mendapatkan informasi berkaitan dengan pola hidup vegetarian dan dampaknya, dilatih membuat masakan vegetarian khas Bali, yang pada akhirnya berkontribusi terhadap kepuasan pelanggan dan penghasilan mitra. Pemerintah juga terbantu dalam menyediakan lapangan pekerjaan dan peningkatan kesejahteraan masyarakat. Kegiatan IbM ini juga dapat meningkatkan pemberdayaan dan pemertahanan masyarakat Bali yang berusaha dalam bidang ekonomi kerakyatan agar mampu bersaing dengan para pendatang, khususnya dalam bisnis kuliner. Selain itu, kegiatan ini juga membantu pemerintah untuk meningkatkan kesejahteraan dan kesehatan masyarakat.

\section{DAFTAR PUSTAKA}

Anonim, 2002. Makanan Tradisional Kaya Fitokimia. Kompas, 8 Agustus 2002. http://www.kompas.com/kesehatan/news/senior/gizi/0208/08/gizi.htm.

Anonim, tt., Kumpulan Resep Vegan Praktis.

Bangun, A.P., 2005. Vegetarian: Pola Hidup Sehat Berpantang Daging. Jakarta: Agromedia Pustaka.

Ching Hai, S. M., 2002. Kunci Pencerahan Seketika. Jakarta: Yayasan Supreme Master Ching Hai Indonesia.

Darmayasa, M., 2000. Vegetarian dan Ahimsa Dharma. Surabaya: Paramita.

Direktorat Gizi Depkes RI, 1981. Daftar Komposisi Bahan Makanan. Jakarta: Bhratara Karya Aksara.

Gsianturi, 2002. Fitokimia Komponen Ajaib Cegak Penyakit jantung Koroner, Diabetes Mellitus, dan Kanker. Kompas. 9 Agustus 2002. http://www.kompas.com/kesehatan/news/senior/gizi/0208/08/gizi.htm. 
Kusharisupeni \& Setiorini, A. (Eds.), 2010. Vegetarian Gaya Hidup Sehat Masa Kini. Yogyakarta: Penerbit Andi.

Latief, A., 1998. Resep Masakan Daerah. Jakarta: CV. Atisa.

Margetts, B. M., et al, 1993. Vegetarians and longevity. Epidemiology, 4(3): 278-279.

Muchtadi, D., 1989. Analisis Pangan. Bogor: PAU Pangan dan Gizi IPB.

Suci, N. K., 1986. Pengolahan Makanan Khas Bali. Denpasar: Proyek Penelitian dan Pengkajian Bali.

Suhandra, I M., 1996. Dharma Caruban (Tuntunan Ngebat). Denpasar: CV. Kayumas Agung.

Suhardana, K., 2010. Ahimsa \& Vegetarian Jalan Menuju Kasih Sayang. Surabaya: Paramita.

Suja, I W., 2012. Mengapa Saya Memilih Vegetarian? Singaraja: Lembaga Pengabdian kepada Masyarakat Universitas Pendidikan Ganesha.

Surayin, I. A., 2007. Masakan Bali. Surabaya: Paramita.

Tim Devisi Penulisan \& Multimedia Move Indonesia, 2007. Vegetarian Hidup Ekologis. Mojokerto: Pusat Pendidikan Lingkungan Hidup (PPLH) Seloliman.

Tjay, T. H. \& Rahardja, K., 2002. Obat-obat Penting: Khasiat, Penggunaan, dan Efekefek Sampingnya. Edisi ke-5. Jakarta: Gramedia.

Walter, P., 1997. Effect of vegetarian diets on aging and longevity. Nutrition reviews $55 ; 61-68$.

Wibawa, M.A., 2005. Vegetarianisme. Surabaya: Paramita.

Wijaya, A. A. N. P. S., 2009. Makanan Satwik \& Kesehatan: Konsep Hidup Masa Lalu untuk Solusi Kesehatan dan Pengembangan Spiritual di Jaman Modern. Surabaya: Paramita. 